\title{
"Conceptual approaches to the formation of regional food security strategy in the context of sustainable development"
}

\begin{tabular}{|c|c|}
\hline \multirow{5}{*}{ AUTHORS } & Marianna Stehnei (D) https://orcid.org/0000-0002-4688-6447 \\
\hline & Inna Irtyshcheva (D https://orcid.org/0000-0002-7025-9857 \\
\hline & Yevheniia Boiko (D https://orcid.org/0000-0003-1874-5433 \\
\hline & Lida Rogatina \\
\hline & Ksenya Khaustova (D https://orcid.org/0000-0002-3062-918X \\
\hline ARTICLE INFO & $\begin{array}{l}\text { Marianna Stehnei, Inna Irtyshcheva, Yevheniia Boiko, Lida Rogatina and Ksenya } \\
\text { Khaustova (2018). Conceptual approaches to the formation of regional food } \\
\text { security strategy in the context of sustainable development. Problems and } \\
\text { Perspectives in Management, 16(4), 42-50. doi:10.21511/ppm.16(4).2018.04 }\end{array}$ \\
\hline DOI & http://dx.doi.org/10.21511/ppm.16(4).2018.04 \\
\hline RELEASED ON & Wednesday, 17 October 2018 \\
\hline RECEIVED ON & Monday, 21 May 2018 \\
\hline ACCEPTED ON & Friday, 21 September 2018 \\
\hline & $(\mathrm{cc})$ EY \\
\hline LICENSE & $\begin{array}{l}\text { This work is licensed under a Creative Commons Attribution } 4.0 \text { International } \\
\text { License }\end{array}$ \\
\hline JOURNAL & "Problems and Perspectives in Management" \\
\hline ISSN PRINT & $1727-7051$ \\
\hline ISSN ONLINE & $1810-5467$ \\
\hline PUBLISHER & LLC "Consulting Publishing Company "Business Perspectives" \\
\hline FOUNDER & LLC "Consulting Publishing Company "Business Perspectives" \\
\hline$\sigma^{0}$ & 三:- \\
\hline NUMBER OF REFERENCES & NUMBER OF FIGURES \\
\hline 29 & 4 \\
\hline
\end{tabular}

(c) The author(s) 2022. This publication is an open access article. 


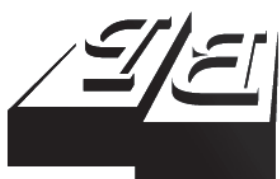

BUSINESS PERSPECTIVES

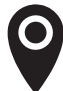

LLC "CPC "Business Perspectives" Hryhorii Skovoroda lane, 10, Sumy, 40022, Ukraine

www.businessperspectives.org

Received on: $21^{\text {st }}$ of May, 2018 Accepted on: $21^{\text {st }}$ of September, 2018

(C) Marianna Stehnei, Inna Irtyshcheva, Yevheniia Boiko, Lida Rogatina, Ksenya Khaustova, 2018

Marianna Stehnei, Doctor of Economic Sciences, Professor of the Department of Finance, Dean of the Faculty of Economics, Management and Engineering, Mukachevo State University, Ukraine.

Inna Irtyshcheva, Doctor of Economic Sciences, Professor, Head of Management Department, National University of Shipbuilding named after Admiral Makarov, Ukraine.

Yevheniia Boiko, Ph.D. Candidate, Public Institution "Institute of Environmental Economics and Sustainable Development of the National Academy of Sciences of Ukraine", Ukraine.

Lida Rogatina, Ph.D., Assistant Professor of the Department of Economic Theory and FinancialEconomic Security, Odessa National Academy of Food Technologies, Ukraine.

Ksenya Khaustova, Ph.D., Assistant Professor of the Department of Management, Mukachevo State University, Ukraine.

\section{(c) (i)}

This is an Open Access article, distributed under the terms of the Creative Commons Attribution 4.0 International license, which permits unrestricted re-use, distribution, and reproduction in any medium, provided the original work is properly cited.
Marianna Stehnei (Ukraine), Inna Irtyshcheva (Ukraine), Yevheniia Boiko

(Ukraine), Lida Rogatina (Ukraine), Ksenya Khaustova (Ukraine)

\section{CONCEPTUAL APPROACHES TO THE FORMATION OF REGIONAL FOOD SECURITY STRATEGY IN THE CONTEXT OF SUSTAINABLE DEVELOPMENT}

\begin{abstract}
The food safety of the region is a fundamental foundation of the country's economic security and one of the most important prerequisites for sustainable development. Unfortunately, the problems of ensuring food security of the regions of Ukraine are not only resolved, but also ultimately aggravated, which negatively affects the quality of life of the population and the development of human potential. An important step in solving the problem of physical and economic food availability to all population is developing a regional food safety strategy. In this regard, the purpose of the article is to develop methodological tools for modeling the region's food security strategy taking into account the peculiarities of its development and existing production and resource potential. The authors explained the concept of "food security strategy", "food safety potential of the region" and methods for assessing its main components. The author's model of the food security strategy creation was developed and implemented on the example of the Ukrainian Black Sea region. This model can be used to monitor the situation with food provision, to model the impact on the state of the food supply of individual strategic decisions and to determine the causes of deviations and growth reserves in any region irrespective of its size or administrative status.
\end{abstract}

\section{Keywords}

\section{JEL Classification}

food security, strategic potential, SPACE analysis, monitoring, regional strategy

\section{INTRODUCTION}

Problems of food security are among the key issues in regional policy. Therefore, management of the sustainable development of the region in the context of food security requires the establishment of an effective mechanism for assessing and monitoring food potential and justifying a strategy that will ensure food security in the long term.

Ensuring the implementation of the strategy of sustainable development of the Black Sea region in accordance with the set goals is only possible if an effective mechanism for the formation, support and use of the potential of industries, resources and territories is created. An important stage in shaping the strategy of the socio-economic development of the Black Sea region is the development of a food supply strategy that forms the preconditions for improving the quality of life, preserving productivity and working capacity of the regional population, regardless of changes in external and internal conditions. In this regard, the actual challenge is to develop strategic tools for modeling a food security strategy, which is based on the present state, trends and factors of its provision. 


\section{LITERATURE REVIEW}

The creation of a regional development strategy in the context of food security requires the study of the essence of the regional food security strategy and its potential.

A great number of scientists research the problems of food security and guaranteed provision of the food supply by the population. Among them are Mccalla and Revoredo (2001), Behnassi et al. (2011), Alexandratos and Bruinsma (2012), Dickerson at al. (2012), Bausch at al. (2014) and others.

Experts Alexandratos and Bruinsma (2013) from the international organization FAO had conducted a comprehensive study of food security in different regions of the world and made a forecast for the future. Their opinion that new resourcesaving technologies and rational use of land resources are needed to prevent food and drinking water shortages is very topical in the modern situation. Therefore, the strategy of food security should be developed by considering the principles of sustainable agricultural development.

Bausch at al. (2014) had carried out the research on the impact of the sustainable development of rural government in different regions of the world on the level of food security. According to the results of their investigations, models of estimation of various factors of influence on the sustainable development of agriculture have been formed, which indirectly affects food safety in different countries.

In scientific papers, the strategy of food security is considered mainly in the context of providing global or national security. For example, the US government has developed a global food security strategy for the period 2017-2021, in which the food security strategy is defined as a "course towards achieving food security and sustainable development of regions and individual countries by combining the efforts of the state authorities, the private sector, research institutions and public organizations in creating favorable conditions for the economic development of the agro-industrial and processing sectors, poverty reduction and the prevention of consequences of climatic impact".
Mccalla and Revoredo (2001) have made a global assessment of food security and have built a global food security forecast that was used to develop the food supply strategy for the selected regions of the world. Their forecast was based on determining the potential of agriculture in the regions and the gap between the needs and food intake.

A group of scientists, including Dickerson, Smith, Ran, and Ori (2012), believe that the foundation for the formation of a strategy for product supply is the study of the impact of the peculiarities of the region's geographical location and the construction on these basis of the clusters of the main commodity positions that are available for consumption.

Some important researches concerning the issues of agricultural sustainable development and its influence on the social effect in some countries were made by Hill, Blandford (2005) and Sekhampu (2013). They have proved that the main objectives of food policy are to ensure equal access to food for all people regardless of social status. Also important are the state subsidies for the development of agriculture as a basis for food and economic security of the country.

Sharafhani, Dustgiri, Garagadji, and Gavanzade (2011) investigated the impact of logistics on the state of food security of households in the regions. According to the results of their research, it was concluded that the strategy of food supply should include the construction of the appropriate infrastructure.

Analytical aspects of food security potential assessment, as well as the formation of agricultural programs and food industry strategy on the global or state level, were reviewed in the works of Hill and Blandford (2005), Jones, Shapiro, and Wilson (2015), Kondra (2014), Cochrane (2017) and other researchers. In particular, Cochrane (2017) developed a mixed method for assessing food potential that combines collaborative participatory methods of quality and collects quantitative data collection tools that provide general information aimed at supporting the development or improvement of policies and programs to enhance food security.

An interesting approach to assessing the potential of food security, which includes a set of indicators of land fertility and their potential increase 
in different regions of Slovakia, was proposed by authors Svetlanská, Turčeková, Adamičková, and Skalský (2017). They consider that the main way to increase food security in the regions is to effectively use existing agricultural potential.

It can be noted that a significant theoretical and methodological basis for research on food security has been developed and a large number of programs to prevent hunger in the world have been implemented. However, some issues concerning food security strategy and its implementation at the level of regions of Ukraine remain relevant.

Unfortunately, the problems of Ukraine's food security are not resolved today and are not well regulated by law. Separate norms for ensuring food security of the state are implemented in a number of regulatory acts, which deal mainly with the agro-industrial complex and not exclusively food issues. The food security strategy is considered in the context of the national strategy of Ukraine (2017-2020), but some issues of food security remain controversial, especially at the current stage of the state development.

The theoretical substantiation of the national security strategy is the subject of the research of many Ukrainian scientists. Mostova (2016) interpreted the state's food security strategy as: "a plan to achieve such a level of development of the state economy and its agrarian sector that is providing the necessary resources and potential, in which the population will be guaranteed stable supply of food in quantity and qualities that meet scientifically substantiated parameters and is creating socio-economic conditions to support medical standards of consumption, regardless of adverse factors in international relations and unfavorable conjuncture in global market".

According to the research by Kolisnyk (2015), "the strategy of food security should be aimed at: providing the necessary amount of food at the expense of own production and, if necessary, at the expense of imports; support for the stability of food supply by reducing supply and crop capacity fluctuations, adequate management of national food supplies, transport infrastructure development and sales systems; ensuring access to all segments of the population to available food".
Taking into account the chosen strategic course of Ukraine's development on the way to European integration, the goals of Ukraine's national food security should be in line with European legislation and standards, and be consistent with the basic principles of the Rome Declaration on World Food Security (1996):

1) ensuring the physical and economic accessibility of consumer goods to meet the energy needs of all social strata;

2) ensuring food independence, that is, autonomy, stability and economic independence of the food system;

3) reliability of the food system, that is, the ability to minimize the influence of seasonal, weather and other factors on the uninterrupted nutrition of the population in all regions;

4) focus on extended playback of the food system.

Given the significant number of interconnected components affecting almost all the spheres of economic activity in the region and the important role in ensuring its socioeconomic security on the way to implementing the mission, the author's definition of the regional food security strategy was proposed: "it is an integral strategy of balanced and stable development of all types of economic activity, which are forming a full cycle of logistical support, production and distribution of vital food products in a sufficient volume that guarantees the needs of a healthy and active life of all strata of the regional population independently from the influence of external and internal threats".

The basic preconditions for developing a regional strategy of the food supply are the substantiation of methodological approaches to assessing the state of food security and the regional potential of its provision as the main constituent elements. In this context, we agree with the statement of Kyrylov (2015) that an important tool for assessing food security in the region is the use of a mathematical device that will allow to build an econometric model for food safety monitoring and the development of appropriate managerial decisions. 
Taking into consideration the objectives of food security of the region and the directions for their implementation, we propose to consider the strategic potential of food security of the region as a set of components, the level of development and interaction, which can provide food security of the region in the long term, regardless of changes in external conditions.

Aims. The purpose of the article is to develop a model of food security strategy in the Black Sea region of Ukraine using the tools of SPACE analysis. To achieve this goal, the following tasks were solved in the article:

- study of methodological approaches to the calculation of regional potential in the field of food security;

- analysis of the potential of food security in the Ukrainian Black Sea region;

- development of the strategy using the SPACE analysis method.

\section{METHODS}

The research has proved that there is no single methodology that would allow to assess and calculate the level of strategic potential of the region or its components, especially in the context of the target approach. At the same time, the most adaptive for the targeted research of strategic potential in the field of food security is a rating integrated method used to rank regions, countries, institutions on various grounds. Such a technique is used by the Institute of Economic Research and Policy Consulting (2013) to determine the investment attractiveness of the Ukrainian regions.

The main components for assessing food supply are medical standards of consumption in the main types of food and the objectives of the food supply. Integral index of the food security potential was calculated by the formula:

$$
R_{S P F S}=\sum_{t}^{n}\left(P_{i} \cdot w\right)
$$

where $R_{S P F S}$ - regional strategic food security potential, $P_{i}$ - component of the food security po- tential of the region, $w$ - weight component of the $P_{i}$ potential.

The food security potential includes such components:

$P_{1}$ - the potential of self-sufficiency of the region by consumer goods of own production, $P_{2}$ - the potential of consumption of goods, $P_{3}$ - the potential of physical availability of consumer goods, $P_{4}$ - the potential of economic availability of consumer goods for the households.

These indicators help in comparative assessments of individual components that increase or decrease the level of food security in the region and may be useful in determining reserves to improve the situation in the strategic perspective.

The calculation of the integral indicator of food security involves the determination of the weighting coefficients $\left(w_{i}\right)$ of each component of the potential, which will determine the degree of their impact or significance in the overall indicator. Taking into account the equivalence of all components for calculating the region's food security potential, the weighting coefficient of each component of the integral indicator was set at 0.25 .

According to the aggregation method, each structural component of the potential includes an established list of the minimum set of socially significant products for the population of the food basket. Accordingly, each individual component of the potential is calculated by the formula:

$$
P_{i}=\sum_{1}^{n} P g_{i} \cdot w_{1}
$$

where $g_{i}$ - partial potential indicator for a particular product type, $w_{i}$ - weighting of the product in the social "grocery basket".

Since the list of the Ukrainian Ministry of Health contains 10 commodity positions of socially significant products, the use of which is a prerequisite for the preservation of physical health and the ability to work, in the article, it was proposed to establish the weighting coefficient of each product at the level of 0.1. 
Table 1. Indicators of assessing the food security potential of the region

Source: Summarized by the authors.

\begin{tabular}{|c|c|c|c|}
\hline No & Indicators & $\begin{array}{l}\text { Formula } \\
\text { of calculation }\end{array}$ & Clarification \\
\hline 1 & $\begin{array}{l}\text { Potential of self- } \\
\text { sufficiency of the region } \\
\text { by consumer goods of } \\
\text { own production }\end{array}$ & $P_{1 g_{i}}=\frac{V_{g_{i}}}{N V_{g_{i}}}$ & $\begin{array}{l}V_{i}-\text { per capita volumes of production of } i \text {-th goods in the region; } \\
N V_{i}-\begin{array}{c}\text { consumption volumes of the } i \text {-th goods in accordance with the } \\
\text { established norms }\end{array}\end{array}$ \\
\hline 2 & $\begin{array}{l}\text { Potential of } \\
\text { consumption of goods }\end{array}$ & $P_{2 g_{i}}=\frac{A C g_{i}}{N V_{g_{i}}}$ & $A C_{i}$ - actual per capita consumption of goods in the region \\
\hline 3 & $\begin{array}{l}\text { Potential of physical } \\
\text { availability of consumer } \\
\text { goods }\end{array}$ & $P_{3 g_{i}}=\frac{T V_{g_{i}}}{T C g_{i}}$ & $\begin{array}{l}T V_{g_{i}} \text {-total volumes of goods production in the region; } \\
T C g_{i} \text { - total consumption of goods in the region }\end{array}$ \\
\hline 4 & $\begin{array}{l}\text { Potential of economic } \\
\text { availability of consumer } \\
\text { goods for the } \\
\text { households }\end{array}$ & $P_{3}=\frac{S_{n}}{S_{a}}$ & $\begin{array}{l}S_{n} \text { - the normative share of household expenditures on foodstuffs; } \\
S_{a} \text { - the actual share of household expenditures on foodstuffs }\end{array}$ \\
\hline
\end{tabular}

The approaches to the calculation of indicators $\left(P_{i}\right)$ for food security potential is well-grounded in the works of Shevchenko (2009), Nikishyna (2012), Kodra (2014), Kolisnyk (2015). Based on their works, food safety potential indicators and the formula for their calculation have been formed (Table 1).

To simplify the process of analyzing individual components of the potential, it was proposed to translate them into points (Table 2).

In accordance with the proposed methodology, formula 2 takes the following form:

$$
P_{i}=\sum_{1}^{n} R g_{i} \cdot w_{i}
$$

Using the 10-point scale makes it easier to interpret metrics at all levels and allows you to better represent the data. In case of exceeding the value of the indices for individual groups of goods over 1 , the points are calculated as the maximum value of this indicator of 10 , and the percentage of excess is considered a reserve for redistribution of the product beyond the region and/or export.

The resulting data calculations will enable to develop an interactive "map of strategic food security potential" with appropriate software that will simulate a food supply strategy in the region and should be useful to monitor the current situation for a specified period of time, coordinate the indicators of the target programs with other regional development strategies and programs.

For the convenience of using and visibility of calculations to forming a "map of the strategic potential of food security", the method of SPACE analysis was used. The advantages of this method are: simple logic of the analysis; relative speed of evaluation in the presence of necessary data; possibility of defining consolidated strategic positions and visibility of the presentation of the results and recommendations on the choice of action lines; opportunity to analyze the chosen strategy even before its implementation.

Table 2. Evaluation of standardized indicators

Source: Adapted by the authors.

\begin{tabular}{|c|c|c|c|c|c|c|c|c|c|c|c|}
\hline \multirow{3}{*}{\begin{tabular}{l}
\multicolumn{1}{c}{ Indexes } \\
Indices \\
value, $g_{i}$
\end{tabular}} & \multicolumn{11}{|c|}{ Rating } \\
\hline & \multirow{2}{*}{$\begin{array}{c}\begin{array}{c}\text { Outstanding } \\
\text { growth }\end{array} \\
>1\end{array}$} & \multicolumn{2}{|c|}{$\begin{array}{l}\text { Threshold } \\
\text { value }\end{array}$} & \multirow{2}{*}{$\begin{array}{c}\begin{array}{c}\text { The first level } \\
\text { of danger }\end{array} \\
0.70-0.79\end{array}$} & \multicolumn{2}{|c|}{ Threat } & \multicolumn{5}{|c|}{$\begin{array}{l}\text { The critical situation in which a food } \\
\text { situation is considered dangerous }\end{array}$} \\
\hline & & $\begin{array}{c}0.90- \\
0.99\end{array}$ & $\begin{array}{c}0.80- \\
0.89\end{array}$ & & $\begin{array}{c}0.60- \\
0.59\end{array}$ & $\begin{array}{c}0.50- \\
0.59\end{array}$ & $\begin{array}{c}0.40- \\
0.49\end{array}$ & $\begin{array}{c}0.30- \\
0.39\end{array}$ & $\begin{array}{l}0.20- \\
0.29\end{array}$ & $\begin{array}{l}0.1- \\
0.09\end{array}$ & $0.08-0$ \\
\hline Points, $R g_{i}$ & 10 & 9 & 8 & 7 & 6 & 5 & 4 & 3 & 2 & 1 & 0 \\
\hline
\end{tabular}


As the main criteria in the work, the components of the region's food security potential in rates have been selected.

The classic version of the SPACE analysis by Rowe R. Mason, Dickel (1982) involves the coordinate division of the scale from -6 to +6 or from 0 to 6 . However, taking into account the peculiarities of assessing the potential of food security, a coordinate division of 0 to 10 points was made in accordance with Table 2.

Combining all the indicators on a single map gives us the opportunity to get a square that limits the field of strategic decisions. The square perimeter represents the scope of food security potential in the region. The larger the perimeter characterizes, the better the situation in the region. The situation is the best when the potential indicators have high scores and are balanced with each other.

The purpose of the article is to develop a model of the strategy for food security in the Black Sea region, which is based on the definition of its strategic potential with using the SPACE analysis tools.

\section{RESULTS}

In order to develop the food security strategy of the Black Sea region, the rating of value potential components was calculated according to the formulae (1-3) by the list of the main socially significant food products (Table 3 ).

The potential of economic availability of food reflects the ability of various social groups to qualitatively and fully eat. The economic availability of products is recommended to be defined as the share of aggregate food costs in aggregate total annual household expenditures (Nikishina, 2012).

As the basis for comparison the index of economic availability of food products, the value of $50 \%$ was taken. As a result of the calculations, the following indicators of economic availability of food products were obtained in rates: Odesa region - 8.1, Mykolaiv region - 8.6, Kherson region - 7.6. The generalized indicator for the Black Sea region is 8.2.

The data obtained from the simulation show that the overall level of food security potential by 2016 is slightly higher than the average (pre-crisis condition).

Table 3. The level of food security potential of the Black Sea region in 2016

Source: Calculated by the authors based on statistic data (2016).

\begin{tabular}{|c|c|c|c|c|c|c|c|c|c|c|c|}
\hline $\begin{array}{c}\text { Indicators of } \\
\text { potential, points }\end{array}$ & $\begin{array}{c}\text { Bread and } \\
\text { bakery } \\
\text { products }\end{array}$ & Potatoes & $\begin{array}{l}\text { Vegetables } \\
\text { and melons }\end{array}$ & $\begin{array}{l}\text { Fruits, } \\
\text { berries, } \\
\text { grapes }\end{array}$ & Sugar & Butter & $\begin{array}{c}\text { Meat } \\
\text { and } \\
\text { meat } \\
\text { products }\end{array}$ & $\begin{array}{l}\text { Fish, fish } \\
\text { products }\end{array}$ & $\begin{array}{l}\text { Milk and } \\
\text { dairy } \\
\text { products }\end{array}$ & Eggs & $\begin{array}{l}\text { Integral } \\
\text { indicator } \\
\text { RSPFS }\end{array}$ \\
\hline \multicolumn{12}{|c|}{ Potential of self-sufficiency (P1) } \\
\hline Odesa region & 4 & 10 & 10 & 3 & 0 & 10 & 2 & 2 & 6 & 5 & 5.2 \\
\hline Mykolaiv region & 6 & 10 & 10 & 3 & 0 & 10 & 3 & 1 & 10 & 8 & 6.1 \\
\hline Kherson region & 10 & 10 & 7 & 1 & 0 & 10 & 5 & 2 & 1 & 5 & 5.1 \\
\hline $\begin{array}{l}\text { On average in } \\
\text { the region }\end{array}$ & 7 & 10 & 9 & 2 & 0 & 10 & 3 & 2 & 6 & 6 & 5.5 \\
\hline
\end{tabular}

\begin{tabular}{|c|c|c|c|c|c|c|c|c|c|c|c|}
\hline \multicolumn{12}{|c|}{ Potential of consumption sufficiency (P2) } \\
\hline Odesa region & 10 & 10 & 7 & 5 & 9 & 10 & 7 & 9 & 7 & 8 & 7.8 \\
\hline Mykolaiv region & 10 & 10 & 7 & 4 & 9 & 10 & 6 & 7 & 7 & 7 & 7.3 \\
\hline Kherson region & 10 & 10 & 6 & 4 & 10 & 10 & 6 & 10 & 6 & 8 & 7.6 \\
\hline $\begin{array}{l}\text { On average in } \\
\text { the region }\end{array}$ & 10 & 10 & 7 & 4 & 9 & 10 & 6 & 9 & 7 & 8 & 7.6 \\
\hline \multicolumn{12}{|c|}{ Potential of physical availability (P3) } \\
\hline Odesa region & 4 & 10 & 10 & 7 & 0 & 10 & 3 & 4 & 7 & 6 & 6.1 \\
\hline Mykolaiv region & 10 & 10 & 10 & 10 & 0 & 9 & 8 & 2 & 10 & 10 & 7.9 \\
\hline Kherson region & 10 & 10 & 10 & 10 & 0 & 9 & 8 & 2 & 10 & 10 & 7.6 \\
\hline $\begin{array}{l}\text { On average in } \\
\text { the region }\end{array}$ & 8 & 10 & 10 & 9 & 0 & 9 & 6 & 3 & 9 & 9 & 7.3 \\
\hline
\end{tabular}


The SPACE analysis method also involves calculating the vector $(\bar{S})$ with coordinates $(0 ; x ; y)$, which determines the choice of the food security strategy of the region, depending on the state of the factors by the formula:

$$
\left\{\begin{array}{l}
x=P_{1}-P_{2} \\
y=P_{4}-P_{3}
\end{array} .\right.
$$

The vectors of the strategic position of the regions of the Black Sea region on the map of the "strategic potential of food security", which were calculated according to the given formula, are shown in Table 4.

Table 4. Calculating the vector of the strategic position of the Black Sea regions

Source: Calculated by the authors.

\begin{tabular}{l|c:c}
\hline \multirow{2}{*}{ The Black Sea regions } & \multicolumn{2}{|c}{ Vector coordinates } \\
\cline { 2 - 3 } & $\mathbf{X}$ & $\mathbf{Y}$ \\
\hline Odesa region & 2 & -2.6 \\
\hline Mykolaiv region & 0.7 & -1.2 \\
\hline Kherson region & 0.3 & -2.5 \\
\hline On average in the region & 0.9 & -2.1 \\
\hline
\end{tabular}

Using the data calculated in Table 4, the strategic position of each region and the Black Sea region as a whole is established on the "strategic potential map", as illustrated in Figure 1. The obtained vector of strategy for all regions of the region is directed to the square P2-P4, that is, the level of consumption of goods exceeds the level of self-suf- ficiency of the region, while the level of physical accessibility is lower than the level of economic accessibility.

It is proposed to focus on increasing the agro-food potential of the region, to create new processing enterprises, and to improve transport and logistics infrastructure. The stated strategic objectives meet the goals and priorities of the approved regional strategies. That is, we can state the sufficient level of coherence of the regional strategy of food security and the strategy of socio-economic development of the Black Sea region.

However, averaged estimates do not give a complete picture of the potential status due to the smoothing of high values of indicators by one category, low capacity values by other categories. For example, a high level of self-sufficiency in the region by the oil of its own production in the integral index overlaps the level of self-sufficiency of the region with sugar, which is almost zero. In addition, the average importance of economic accessibility does not take into account the structure of the population in the region and the share of food expenditure by different segments of the population. In this regard, using this methodical toolkit, it is necessary to conduct the analysis of capacity by sector and in the context of food products.

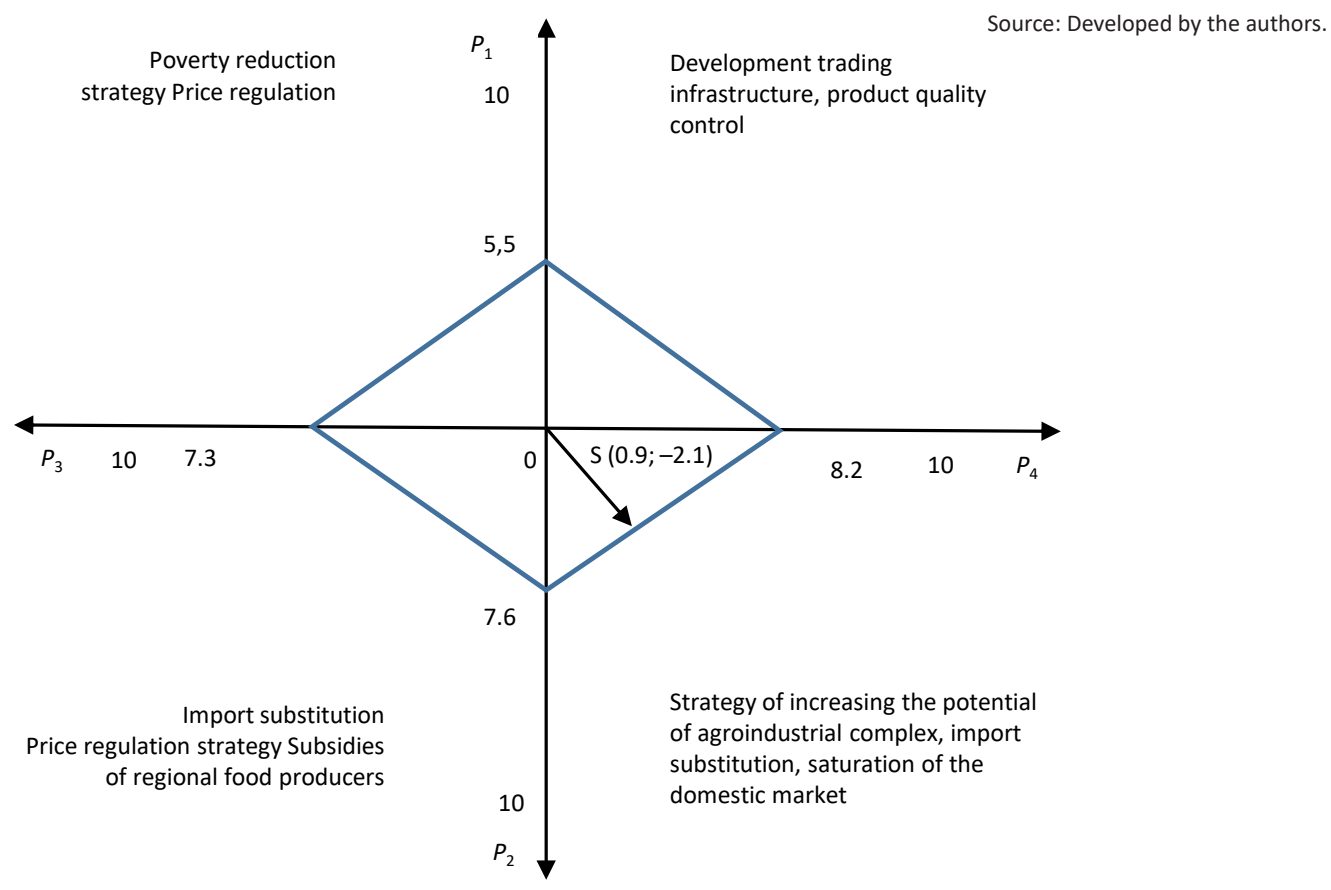

Figure 1. Map of the strategic potential of food security in the Black Sea region 


\section{CONCLUSION}

The research has convinced that food security should become a priority strategic task in the context of sustainable development of the Black Sea region. Therefore, the region needs a scientifically substantiated and comprehensively developed Food Security Strategy for the future, at least for the period up to 2020 that includes not only the potential of individual regions, but also the potential for their interaction. This is possible due to the strengthening of interregional coordination in the direction of production and redistribution of consumer goods, the creation of food reserves, the development of logistics infrastructure and the active implementation of modern technologies in the development of agro-processing industries.

The methodical approaches to the formation of a "map of food potential of the region" based on the principles of SPACE analysis are substantiated in this paper. This methodology involves calculating the food security potential of the region based on four groups of criteria (self-sufficiency potential, physical accessibility potential, economic availability and capacity of consumption adequacy), and a strategic map showing the overall status of the indicators at the time of evaluation and in the future. The map contains four sectors that characterize possible combinations of strategic alternatives. The definition of a food security strategy is based on a calculated vector, which is directed to a specific sector and characterizes the state of the investigated factors for the set period of time.

Approbation of the proposed methodology for modeling the strategy of food supply of the region showed its practical significance and availability in use. The effectiveness of the method depends, first of all, on the creation of a database containing surveyed indicators in terms of areas, goods and industries and replenished with the established periodicity.

\section{REFERENCES}

1. Abdulkadyrova, M. A., Dikinovb, A. H., Tajmashanova, H. Ė., \& Shidaeva, L. A. (2016). Global food security problems in the modern world economy. International Journal of Environmental \& Science Education, 11(12), 5320-5330. Retrieved from http://www.ijese. net/makale/709

2. Alexandratos, N., \& Bruinsma, J. (2012). World agriculture towards 2030/2050: The 2012 revision. Global Perspective Studies Team. Retrieved from http://www.fao.org/ docrep/016/ap106e/ap106e.pdf

3. Battisti, D. S., \& Naylor, R. L. (2009). Historical warnings of future food insecurity with unprecedented seasonal heat. Science, 323, 240-244. https://doi.org/10.1126/ science. 1164363

4. Bausch, J. C., Bojórquez-Tapia, L., \& Eakin, H. (2014). Agro-environmental sustainability assessment using multicriteria decision analysis and system analysis. Sus- tainability Science, 9(3), 303-319. https://doi.org/10.1007/s11625014-0243-y

5. Behnassi, M., Draggan, S., \& Yaya, S. (2011). Global food insecurity (127 p.). Dordrecht, New York, Heidelberg, London: Springer.

6. Cochrane, L. (2017). Stages of food security: A co-produced mixed-methods methodology. Progress in development studies, 17(4), 291-306. https://doi. org/10.1177/1464993417716358

7. FAO (1996). Rome Declaration on World Food Security and World Food Summit Plan of Action. World Food Summit (36 p.).

8. Gorham, J. R., \& Zurek, L. (2006). Filth and other foreign objects in foods: a review of analytical methods and health significance. Taylor and Francis, CRC press, Boca Raton, FL.

9. Herdt, R. W. (2004). Food Shortages and International Agricul- tural Programs. Critical Reviews in Plant Sciences, 23(6), 505.

10. Hill, B., \& Blandford, D. (2005). Structural Change in EU Agriculture and the Supply of Social Attributes. Paper presented at XI Congress of the EAAE The Future of Europe in the Global Agri-Food System, Copenhagen, Denmark. Retrieved from http:// ageconsearch.umn.edu/bitstream/24684/1/os05hi01.pdf

11. Jones, A. D., Shapiro, L., \& Wilson, M. L. (2015). Assessing the Potential and Limitations of Leveraging Food Sovereignty to Improve Human Health. Front. Public Health. https://doi.org/10.3389/ fpubh.2015.00263

12. Kolisnyk, H. M. (2015). Продовольча безпека України та особливості їі розвитку [Prodovolcha bezpeka Ukrainy ta osoblyvosti yii rozvytku]. Sotsialno-ekonomichni problemy suchasnoho periodu Ukrainy, 5, 
72-76. Retrieved from http:// www.irbis-nbuv.gov.ua/cgi-bin/ irbis_nbuv/cgiirbis_64.exe?I21 $\mathrm{DBN}=\mathrm{LINK} \& \mathrm{P} 21 \mathrm{DBN}=\mathrm{UJRN}$ $\& Z 21 \mathrm{ID}=\& S 21 \mathrm{REF}=10 \&$ \&21C $\mathrm{NR}=20 \&$ S21STN $=1 \&$ S21FMT $=$ ASP_meta $\&$ C $21 \mathrm{COM}=\mathrm{S} \& 2$ S21P03=FILA=\&2

S21STR=sepspu_2015_5_19

13. Kondra, O. R. (2014). Оцінювання стану продовольчої безпеки регіону [Otsiniuvannia stanu prodovolchoi bezpeky rehionu]. Rehionalna ekonomi$k a, 4,78-86$. Retrieved from http://ird.gov.ua/pe/re201404/ re201404_078_KondraOR.pdf

14. Kyrylov, Y. E. (2015).

Кониептуальні засади конкурентоспроможного розвитку аграрного сектора економіки України в умовах глобалізаиіï [Kontseptualni zasady konkurentospromozhnoho rozvytku ahrarnoho sektora ekonomiky Ukrainy $v$ umovakh hlobalizatsii] (420 p.). Kherson: OLDI-PLYUS.

15. Mccalla, A. F., \& Revoredo, C. L. (2001). Prospects for global food security: a critical appraisal of past projections and predictions (73 p.). International food policy research institute.

16. Mostova, A. D. (2016). Стратегія продовольчої безпеки держави: теоретико-методичний аспект [Stratehiia prodovolchoyi bezpeky derzhavy: teoretykometodychnyi aspekt]. Ekonomika ta derzhava, 5, 38-42. Retrieved from http://www.economy. in.ua/?op $=1 \& \mathrm{z}=3517 \& \mathrm{i}=6$

17. Nikishyn, Y. E. (2014). Формування стратегіi продовольчого забезпечення регіону як фактора економічної безпеки України [Formuvannia stratehii prodovolchoho zabezpechennia rehionu yak faktora ekonomichnoi bezpeky Ukrainy]. Vcheni zapysky universytetu "KROK". Seriia: Ekonomika, 38, 9-17. Retrieved from http://nbuv. gov.ua/UJRN/Vzuk_2014_38_4

18. Nikishyna, O. V. (2012). Оцінка стану продовольчої безпеки Одеського регіону [Otsinka stanu prodovolchoi bezpeky
Odeskoho rehionu]. Ekonomika kharchovoi promyslovosti, 1(13), 9-16.

19. Rosset, P. M., \& Martínez-Torres, E. (2012). Rural social movements and agroecology: context, theory, and process. Ecology and Society, 17(3), 17. http://dx.doi. org/10.5751/ES-05000-170317

20. Rowe, H., Mason, R., \& Dickel, K. (1982). Strategic Management and Business Policy: A Methodological Approach (155 p.). Wesley Publishing Co. Inc.

21. Sekhampu, T. (2013). Determination of the factors affecting the food security status of households in Bophelong, South Africa. International business and economics research journal, 12(5), 543-549. https://doi.org/10.19030/iber. v12i5.7829

22. Sharafkhani, R., Dastgiri, S., Gharaaghaji, A. R., \& Ghavamzadeh, S. (2011). Factors influencing household food security status. Food and nutrition sciences, 2, 31-34. https://doi.org/10.4236/ fns.2011.21004

23. Shevchenko, O. O. (2009). Критерії та показники оцінки регіональної продовольчої безпеки [Kryterii ta pokaznyky otsinky rehionalnoi prodovolchoi bezpeky]. Aktualni problemy derzhavnoho upravlinnia, 1, 188-195.

24. Svetlanská, T., Turčeková, N., Adamičková, I., \& Skalský, R. (2017). Food security facets: case of Slovakia regions. Journal of security and sustainability issues, 7(2), 311-320. https://doi. org/10.9770/jssi.2017.7.2(11)

25. United Nations (2012). The Future We Want: Outcome Document from Rio + 20 United Nations Conference on Sustainable Development. New York.

26. Yeremeichuk, R. A. (2013). Використання збалансованої системи показників і простіраналіз для визначення стратегії банку [Vykorystannia zbalansovanoi systemy pokaznykiv i prostiranaliz dlia vyznachennia stratehii banku]. Biznes Inform, 8, 277-284. Retrieved from http://nbuv.gov.ua/ UJRN/binf_2013_8_49
27. Державна служба статистики [Derzhavna sluzhba statystyky] (2016). Регіони України [Rehiony Ukrainy] (Part 2, 685 p.).

28. Інститут економічних досліджень та політичних консультацій [Instytut ekonomichnykh doslidzhen ta politychnykh konsultatsii] (2014). Рейтинг інвестиційноі привабливості регіонів [Reitynh investytsiinoi pryvablyvosti rehioniv] (356 p.). Kyiv. Retrieved from http://fru.ua/images/doc/ reyting_investiciynoyi_privablivosti_regioniv_2014_1.pdf

29. Стратегія національної безпеки України [Stratehiia natsionalnoi bezpeky Ukrainy] (2007). Retrieved from http://zakon0.rada. gov.ua/laws/show/105/2007 